ISSN 1392-3196 / e-ISSN 2335-8947

Zemdirbyste-Agriculture, vol. 105, No. 2 (2018), p. 99-104

DOI 10.13080/z-a.2018.105.013

\title{
Mineral nitrogen in soils of Lithuania's agricultural land: comparison of oven-dried and field-moist samples
}

\author{
Jonas ARBAČAUSKAS, Aistė MASEVIČIENĖ, Lina ŽIČKIENÉ, \\ Gediminas STAUGAITIS \\ Agrochemical Research Laboratory, Lithuanian Research Centre for Agriculture and Forestry \\ Savanorių 287, Kaunas, Lithuania \\ E-mail: bandymai@agrolab.lt
}

\begin{abstract}
Mineral nitrogen $\left(\mathrm{N}_{\min }=\mathrm{N}-\mathrm{NH}_{4}^{+}+\mathrm{N}^{-\mathrm{NO}_{3}}{ }^{-}\right)$in oven-dried and field-moist samples was investigated in 20112014 in five areas of Lithuania with soils of different texture (sand, sandy loam, loam and clay) and different mineral nitrogen $\left(\mathrm{N}_{\min }\right)$ content. The samples were taken in spring (from late March to early April) and autumn (late October - early November), from the 0-30, 30-60 and 60-90 cm as well as from 0-60 cm soil layers. The aim of the research was to determine the influence of different methods of soil sample preparation on the concentrations of ammonium $\left(\mathrm{N}-\mathrm{NH}_{4}^{+}\right)$and nitrate $\left(\mathrm{N}-\mathrm{NO}_{3}{ }^{-}\right)$nitrogen in oven-dried and field-moist samples and to assess the suitability of the obtained results for the development of agricultural plant fertilisation plans.

According to the research results, drying of soil samples at a temperature of $35^{\circ} \mathrm{C}$ for 12 hours resulted in

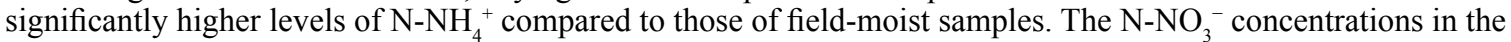
field-moist samples, when stored at a $4^{\circ} \mathrm{C}$ temperature for 3 days, increased marginally compared to the oven-dried soil samples. Weak or moderate, however, statistically significant correlations were observed between $\mathrm{N}-\mathrm{NH}_{4}^{+}$ concentrations in the oven-dried and field-moist samples. In order to perform faster chemical analyses of soil $\mathrm{N}_{\text {min }}$ for making agricultural plant fertilisation plans, it is necessary to carry out analyses on oven-dried soil samples, and using the linear correlation equations, to convert the results of $\mathrm{N}^{-\mathrm{NH}_{4}}{ }^{+}$analyses into field-moisture data.
\end{abstract}

Keywords: ammonium and nitrate nitrogen, preparation of samples for analysis.

\section{Introduction}

Nitrogen $(\mathrm{N})$ is vital for all living organisms and it is of utmost importance for the increase of agricultural productivity, which facilitates solving the problems of supplying human population with food globally to a large extent (Prud'homme, 2005; Wiesler, Armbruster, 2009).

Although nitrogen is one of the key factors shaping fertility of soil and productivity of plants, its abundance can cause damage to the environment (Füleky, 2009; Rutkowska, Fotyma, 2009). By virtue of an intensive use of nitrogen fertilisers, where fertiliser rates exceed plant needs, and in the case of other nutrient shortage in soil the nitrates unused by plants enter surface and ground waters causing pollution (Bouwman et al., 2005; Adomaitis et al., 2008; Eriksen et al., 2008). All of this may have a negative impact both on the health status of people and wildlife (WHO, 1985). Therefore, in 1991 the European Commission published the Nitrates Directive (91/676/EEC) concerning the protection of waters against pollution caused by nitrates from agricultural sources, which prescribes the limit of groundwater pollution contamination by nitrates $50 \mathrm{mg} \mathrm{l}^{-1}$ (Council Directive, 1991).

After harvesting, $\mathrm{N}^{-\mathrm{NO}_{3}}{ }^{-}$that was not absorbed by plants and remaining in soil is identified as the main source of nitrate leaching in winter (Bogaert et al., 2000).
Therefore, it is imperative, that in autumn $\mathrm{N}-\mathrm{NO}_{3}{ }^{-}$quantities in soil are as low as possible and its leaching to ground water is not increased (Rutkowska, Fotyma, 2009).

In order to reduce nitrate leaching, in Lithuania, Germany, Poland and other European countries nitrogen fertiliser rates for agricultural crops are determined taking account of mineral nitrogen $\left(\mathrm{N}_{\text {min }}\right)$ levels present in soil in spring. Soil samples are taken in autumn in order to determine the concentrations of these compounds remaining in soil after harvesting (Staugaitis et al., 2007; Arbačiauskas et al., 2014).

Mineral nitrogen concentration in a specific soil layer in real place and time reflects the balance of nitrogen released during organic matter mineralisation as well as that incorporated with mineral and organic fertilisers and fixed by microorganisms on the one hand, and nitrogen assimilated by plants, leached, denitrified and immobilised on the other hand (Wong, Nortcliff, 1995).

Therefore, it is very important to take soil samples properly and prepare them for chemical analyses. If soil samples are taken from soils untypical for the area and they are inadequately prepared, chemical analyses do not indicate accurate $\mathrm{N}_{\min }$ concentrations in the analysed field soil (Anderson, Ingram, 1993). To prepare an average soil sample is complicated as in outdoor conditions such

Please use the following format when citing the article:

Arbačauskas J., Masevičienè A., Žičkienè L., Staugaitis G. 2018. Mineral nitrogen in soils of Lithuania's agricultural land: comparison of oven-dried and field-moist samples. Zemdirbyste-Agriculture, 105 (2): 99-104 DOI 10.13080/z-a.2018.105.013 
sample is composed of $10-15$ borings and for chemical analyses only $25 \mathrm{~g}$ of soil is required. Thus, in preparing an average soil sample it is easier, and chemical analyses can be conducted faster to mix oven dried soil compared to field-moist soil (Vandendriessche et al., 2011; Deressa, 2014). This is particularly important since intensive biochemical transformation of nitrogen compounds takes place in soil: ammonification, nitrification, fixation in soil sorption complex, denitrification and evaporation depending on soil moisture, temperature and other factors. It is also noted that sample drying affects the results of ammonium and nitrate analyses (Gray, McLaren, 2003; Nina, Sigunga, 2012).

Soil sample storage prior to chemical analyses may still allow continuation of ammonification and denitrification processes in soil depending on storage conditions (Gray, McLaren, 2003; Nina, Sigunga, 2012). Nitrogen concentrations in soil and fertilisation recommendations for farmers, therefore, have to be carried out as soon as possible (Mengel, Kirkby, 2001; Staugaitis et al., 2007). Studies relating to the influence of soil sample preparation for chemical analyses on mineral

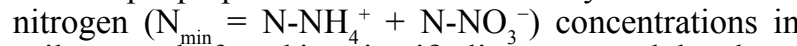
soil are rarely found in scientific literature, and they have never been carried out under the conditions of our country.
Experience has shown that different $\mathrm{N}_{\min }$ determination methods can yield discrepant results.

Therefore, the aim of this work is to determine the influence of different methods of soil sample preparation on the concentrations of ammonium $\left(\mathrm{N}_{-} \mathrm{NH}_{4}^{+}\right)$and nitrate $\left(\mathrm{N}-\mathrm{NO}_{3}{ }^{-}\right)$nitrogen in oven-dried and field-moist samples and to assess their suitability for preparing agricultural plant fertilisation plans in different soils of Lithuania's agricultural land.

\section{Materials and methods}

The studies were conducted in 2011-2014 in five locations (Table 1). Three of them (No. 1, 2 and 3 ) were agricultural land areas located in three parts of Lithuania-Western, Central and Eastern. 5-7 sites were selected in each of the aforementioned areas 5-7 on the soils of different types and different texture (sand, sandy loam, loam and clay). For other two (No. 4 and 5) research sites, the data from the experiments carried out in Central and Eastern Lithuania on agricultural crop fertilisation were used. Soil texture in the subsoil of all investigated sites was heavier compared to the arable soil layer. The agrochemical characteristics of the soil from the study sites are presented in Table 1 .

Table 1. Soil agrochemical characteristics of study sites

\begin{tabular}{|c|c|c|c|c|c|}
\hline \multirow[t]{2}{*}{ No. } & \multirow{2}{*}{$\begin{array}{l}\text { Coordinates of } \\
\text { study site }\end{array}$} & \multirow{2}{*}{$\begin{array}{l}\mathrm{pH}_{\mathrm{KCl}} \\
\pm \mathrm{SD}\end{array}$} & $\begin{array}{c}\text { Soil organic } \\
\text { carbon* }\end{array}$ & $\begin{array}{c}\text { Total } \\
\text { nitrogen }^{* *}\end{array}$ & \multirow{2}{*}{$\begin{array}{c}\begin{array}{c}\text { Mineral } \\
\text { nitrogen }\end{array} \\
\mathrm{mg} \mathrm{kg}^{-1} \pm \mathrm{SD}\end{array}$} \\
\hline & & & \multicolumn{2}{|c|}{$\% \pm \mathrm{SD}$} & \\
\hline 1. & $x 409428, y 6158486$ & $6.4 \pm 0.27$ & $2.57 \pm 0.22$ & $0.200 \pm 0.078$ & $7.41 \pm 3.56$ \\
\hline 2. & $x 435370, y 6062869$ & $6.9 \pm 0.32$ & $1.31 \pm 0.27$ & $0.128 \pm 0.046$ & $5.73 \pm 1.31$ \\
\hline 3. & $x 574244$, y 6158473 & $5.1 \pm 0.47$ & $0.85 \pm 0.24$ & $0.084 \pm 0.007$ & $5.94 \pm 3.18$ \\
\hline 4. & $x 484218$, y 6159972 & $6.6 \pm 0.30$ & $1.56 \pm 0.15$ & $0.160 \pm 0.018$ & $10.8 \pm 4.02$ \\
\hline 5. & $x 573594$, y 6158511 & $5.3 \pm 0.42$ & $1.25 \pm 0.12$ & $0.120 \pm 0.013$ & $9.92 \pm 3.42$ \\
\hline
\end{tabular}

SD - standard deviation; * - ISO 10694:1995. Soil quality - Determination of organic and total carbon after dry combustion, ** ISO 11261:1995. Soil quality - Determination of total nitrogen by modified Kjeldahl method

Soil samples were taken in spring (end of March - beginning of June) and autumn (end of October - beginning of November) at depths of 0-30, 30-60 and $60-90 \mathrm{~cm}$ as well as from the $0-60 \mathrm{~cm}$ soil layer from $10 \times$ $10 \mathrm{~m}$ size sites (in the case of agricultural crop fertilisation experiments - from $6 \times 12 \mathrm{~m}$ size sites). Each soil sample was composed of 10 borings, homogenised well, packed in a plastic bag and stored at $4^{\circ} \mathrm{C}$ for three days. According to ISO 14256-2:2005 (Soil quality - Determination of nitrate, nitrite and ammonium in field-moist soils by extraction with potassium chloride solution. Part 2. Automated method with segment flow analysis), this is the maximum permitted storage time for soil samples.

Upon arrival to the laboratory, the field-moist soil samples were prepared by moist soil homogenizer "Vaichenstefen" No. 69/26.5.4899 (Germany). After that the sample was placed on the table and shaped into a square and then diagonally divided into four sections. The sample portion made of two opposite square sections was used for ammonium $\left(\mathrm{N}-\mathrm{NH}_{4}^{+}\right)$and nitrate $\left(\mathrm{N}-\mathrm{NO}_{3}^{-}\right)$ nitrogen determination in the field moisture condition. This sample portion was weighed by a standard operating procedure SVP D-10:2016. Meanwhile, the other part of the sample was poured back into the same plastic bags and used for the analysis of the mentioned elements having dried the soil beforehand. Prior to the analyses to be carried out on the oven-dried samples they had been dried at $35^{\circ} \mathrm{C}$ for at least 12 hours. The soil dried in the oven was ground, sieved through a $2 \mathrm{~mm}$ sieve and a $20 \mathrm{~g}$ sample was taken from it for chemical analysis.
The determination of $\mathrm{N}-\mathrm{NH}_{4}^{+}$and $\mathrm{N}_{-} \mathrm{NO}_{3}{ }^{-}$ concentrations in soil samples was performed in accordance with ISO 14256-2:2005. The field-moist samples were analysed using a soil extractant ratio of 1:5. $40 \mathrm{~g}$ soil was weighed into a $500 \mathrm{ml}$ plastic bottle and $200 \mathrm{ml} 1 \mathrm{~mol}$ $\mathrm{l}^{-1} \mathrm{KCl}$ added. Next, the samples were shaken in a shaker for 1 hour at ambient temperature $20 \pm 2^{\circ} \mathrm{C}$. Then, the suspension was strained using a paper filter into test tubes, decanting the first drops of the filtrate (about $20 \mathrm{ml}$ ). The paper filter contamination by nitrogen compounds was verified. Next, the extraction solution was filtered through a filter paper into test tubes. The determined nitrogen compounds were compared with the extraction solution and with their concentrations in the extraction solution. In parallel with the sample analysis the blank test was carried out in accordance with the same procedure using the same quantities of all reagents as in the sample analysis only without the experimental material (soil).

Soil and extractant ratio used for the analysis of the oven-dried samples was also 1:5. $20 \mathrm{~g}$ of soil were weighed into a $250 \mathrm{ml}$ plastic bottle. The measure of $100 \mathrm{ml} \mathrm{l}^{-1} \mathrm{KCl}$ was taken and added. Subsequently, the same analysis procedure as described for determining nitrogen concentration in the field-moist samples was applied.

Next, $\mathrm{N}-\mathrm{NH}_{4}^{+}$and $\mathrm{N}-\mathrm{NO}_{3}{ }^{-}$concentrations were analysed using analyser Fiastar 5000 (FOSS Analytical AB "Kongas", Sweden). The measurements were carried out immediately after the filtrate preparation by this device under its instructions for use. Special cassettes with appropriate filters were used for $\mathrm{N}-\mathrm{NO}_{3}{ }^{-}$and $\mathrm{N}-\mathrm{NH}_{4}{ }^{+}$ determination. 
The mineral nitrogen $\left(\mathrm{N}_{\text {min }}\right)$ data derived from the analyses of the field-moist soil samples were converted to dry moisture according to the following formula:

$$
y_{l}, y_{2}=\left[\frac{\frac{x_{l}: x_{2}}{v}}{m}\right] \times\left[\frac{v}{m} \times\left(1+\frac{w_{w}}{100}\right)+\frac{w_{w}}{100}\right],
$$

where $y_{1}$ is $\mathrm{N}-\mathrm{NH}_{4}$ concentration $\left(\mathrm{mg} \mathrm{kg}^{-1}\right)$ conversion into dry soil, $y_{2}-\mathrm{N}-\mathrm{NO}_{3}$ concentration (mg $\mathrm{kg}^{-1}$ ) conversion into dry soil, $x_{1}-\mathrm{N}-\mathrm{NH}_{4}$ concentration $\left(\mathrm{mg} \mathrm{kg}^{-1}\right)$ in field-moist soil, $x_{2}-\mathrm{N}-\mathrm{NO}_{3}$ concentration $\left(\mathrm{mg} \mathrm{kg}^{-1}\right)$ in field-moist soil, $m$ - soil sample weight used for the extraction $(40 \mathrm{~g}), V$ - extraction solution volume $(200 \mathrm{ml}), w_{w}-$ soil water content by weight $\%$ calculated for dry soil.

Statistical analysis. The experimental data on $\mathrm{N}-\mathrm{NH}_{4}^{+}$and $\mathrm{N}^{+} \mathrm{NO}_{3}{ }^{-}$was statistically processed using software Microsoft Office Excel 2010. Mean $\mathrm{N}_{-} \mathrm{NH}_{4}^{+}$ and $\mathrm{N}_{-} \mathrm{NO}_{3}^{-}$concentrations and their ratios as well as standard deviations (SD) were calculated. To assess the significance of a two-sample average $t$ test was applied. At a selected probability level $(p \leq 0.01$ and $p \leq 0.05)$ a factual $t_{\text {fact }}$ criterion value was compared with a theoretical $t_{\text {theor }}$ value and the difference between the two means was recognised as significant, when $t_{\text {fact }} \geq t_{\text {theor }}$. To determine the strength and nature of the relationship between the variables, correlation and regression data analysis was performed using software STATISTICA 7 (Hill, Levicki, 2005).

\section{Results and discussion}

Ammonification is organic nitrogen transformation into $\mathrm{NH}_{4}^{+}$involving soil microorganisms (Galloway et al., 2004). With a temperature increase the intensity of ammonification increases as well (Sparling, Ross, 1988).

Having analysed ammonium nitrogen $\left(\mathrm{N}_{-} \mathrm{NH}_{4}^{+}\right)$ concentrations in all of our studied soils we established significantly higher levels of it in the oven-dried samples compared to the field-moist samples, which is contrary in the case of nitrate $\left(\mathrm{N}_{-} \mathrm{NO}_{3}{ }^{-}\right)$(Table 2). The concentrations of this element found in the field-moist samples at 0-30, 30-60 and 60-90 cm depths were 1.56, 0.75 and $0.62 \mathrm{mg} \mathrm{kg}^{-1}$ higher, respectively compared to the oven-dried samples. The $\mathrm{N}_{-} \mathrm{NH}_{4}^{+}$concentration ratio between the oven-dried and field-moist samples at the upper $(0-30 \mathrm{~cm})$ soil layer was lower $(1: 0.39)$ and in the deeper 30-60 and 60-90 cm layers it was higher (1:0.52 and 1:0.58, respectively). In the case of light texture

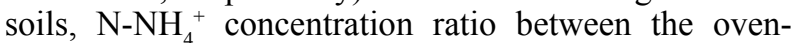
dried and field-moist samples at the $0-30 \mathrm{~cm}$ layer was insignificantly lower, while at the $60-90 \mathrm{~cm}$ depth it was higher, respectively, compared to heavy texture soils.

Our studies found that even when the samples had been stored at $4^{\circ} \mathrm{C}$ for three days prior to chemical analyses, the nitrification processes continued, therefore, the nitrate nitrogen $\left(\mathrm{N}_{-} \mathrm{NO}_{3}^{-}\right)$concentrations in the field-

Table 2. Ammonium $\left(\mathrm{N}_{-} \mathrm{NH}_{4}^{+}\right)$and nitrate $\left(\mathrm{N}^{-} \mathrm{NO}_{3}{ }^{-}\right)$nitrogen concentrations in oven-dried and field-moist samples of different texture soils

\begin{tabular}{|c|c|c|c|c|}
\hline \multirow{4}{*}{$\begin{array}{l}\text { Depth } \\
\mathrm{cm}\end{array}$} & \multicolumn{2}{|c|}{$\mathrm{N}-\mathrm{NH}_{4}^{+}$} & \multicolumn{2}{|c|}{$\mathrm{N}-\mathrm{NO}_{3}^{-}$} \\
\hline & \multicolumn{4}{|c|}{ oven-dried samples } \\
\hline & \multicolumn{4}{|c|}{ field-moist samples } \\
\hline & $\mathrm{mg} \mathrm{kg}^{-1}$ & ratio & $\mathrm{mg} \mathrm{kg}^{-1}$ & ratio \\
\hline \multicolumn{5}{|c|}{ Heavy texture soils: loams, clays (cases 432 ) } \\
\hline \multirow[b]{2}{*}{$0-30$} & $2.64 * *$ & 1 & 5.64 & 1 \\
\hline & 1.04 & 0.39 & $6.82 * *$ & 1.20 \\
\hline \multirow{2}{*}{$30-60$} & $1.65^{* *}$ & 1 & 3.83 & 1 \\
\hline & 0.87 & 0.52 & $4.37 *$ & 1.14 \\
\hline \multirow{2}{*}{$60-90$} & $1.52 * *$ & 1 & 2.65 & 1 \\
\hline & 0.87 & 0.57 & 3.01 & 1.13 \\
\hline \multicolumn{5}{|c|}{ Light texture soils: sands, sandy loams (cases 87 ) } \\
\hline \multirow{2}{*}{$0-30$} & $2.14 * *$ & 1 & 4.11 & 1 \\
\hline & 0.78 & 0.36 & 4.63 & 1.13 \\
\hline \multirow{2}{*}{$30-60$} & $1.33 * *$ & 1 & 2.69 & 1 \\
\hline & 0.70 & 0.52 & 3.28 & 1.22 \\
\hline \multirow{2}{*}{$60-90$} & $1.17 * *$ & 1 & 1.86 & 1 \\
\hline & 0.71 & 0.60 & 2.11 & 1.14 \\
\hline \multicolumn{5}{|c|}{ All soils (cases 519) } \\
\hline \multirow{2}{*}{$0-30$} & $2.56^{* *}$ & 1 & 5.39 & 1 \\
\hline & 1.00 & 0.39 & $6.45 * *$ & 1.20 \\
\hline \multirow{2}{*}{$30-60$} & $1.59 * *$ & 1 & 3.64 & 1 \\
\hline & 0.84 & 0.52 & $4.19 * *$ & 1.15 \\
\hline \multirow{2}{*}{$60-90$} & $1.46^{* *}$ & 1 & 2.52 & 1 \\
\hline & 0.84 & 0.58 & $2.86^{*}$ & 1.13 \\
\hline
\end{tabular}

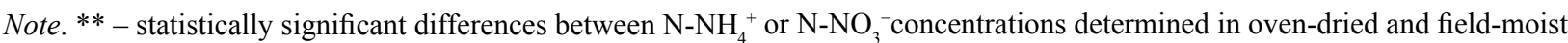
samples at the $99 \%$ probability $(p \leq 0.01) ;{ }^{*}$ - differences statistically significant at the $95 \%$ probability $(p \leq 0.05)$.

moist samples were statistically significantly higher compared to the concentration of this element in the oven dried samples (Table 2). However, these changes were more pronounced in the soils of heavier texture compared to light sands of sandy loams.

In Belgium, the researchers found that the sample preparation method to establish $\mathrm{N}_{-} \mathrm{NO}_{3}{ }^{-}$concentrations did not influence the determination itself, when the samples were analysed immediately on arrival from the field, storing them at $4^{\circ} \mathrm{C}$. However, it confirmed the tendencies achieved by us, that longer storage time of soil samples, even at $4^{\circ} \mathrm{C}$, allows further biological oxidation of ammonium to nitrate (nitrification) (Vandendriessche et al., 2011). There is evidence that biological nitrification processes in soil take place even when soil samples are stored at $-10^{\circ} \mathrm{C}$ (Magesan et al., 2002; Nina, Sigunga, 2012). Meanwhile, soil sample drying stops this processes in soil (Vandendriessche et al., 2011). In moist soil oxygen stimulates the activity of nitrifying bacteria resulting in an increased nitrate $\left(\mathrm{NO}_{3}^{-}\right)$content 
in the samples during their storage. This is determined by oxygen access to the soil during sample preparation and storage. As Alvarez and Steinbach (2009) indicate soil tillage results in improved soil aeration, which influences the increase in $\mathrm{N}^{-} \mathrm{NO}_{3}{ }^{-}$content compared to untilled soil. This can also be applied in the case of soil sampling, when more oxygen enters soil.

The concentrations of $\mathrm{N}^{-\mathrm{NO}_{3}}{ }_{3}^{-}$distributed in a consistently decreasing sequence at different $(0-30,30$ 60 and $60-90 \mathrm{~cm}$ ) soil layers, and in deeper soil layers it was lower compared to the top 0-30 cm layer. The concentrations of $\mathrm{N}^{-\mathrm{NO}_{3}}{ }^{-}$in the field-moist samples at depths of $0-30,30-60$ and $60-90 \mathrm{~cm}$ were $1.06,0.55$ and $0.34 \mathrm{mg} \mathrm{kg}^{-1}$ higher, respectively, compared to the concentrations of this element established in the ovendry samples. The dependence tendencies of this element concentrations on the soil layer depth expressed in relative numbers was the same as that assessed in actual figures. If the ratio between $\mathrm{N}-\mathrm{NO}_{3}{ }^{-}$concentrations in the oven-dried and field-moist samples at the $0-30 \mathrm{~cm}$ soil layer was 1.20, deeper 30-60 and 60-90 cm layers demonstrated ratios of 1.15 and 1.13 , respectively.

In the case of heavier texture soils, the ratios of the established $\mathrm{N}_{-} \mathrm{NO}_{3}{ }^{-}$concentrations in the fieldmoist samples and the concentrations of this element in the oven-dry samples as well as the variation tendencies achieved were the same as in overall assessment of all the soils.

The $\mathrm{N}_{-} \mathrm{NO}_{3}{ }^{-}$concentrations in light textured soils were lower compared to those in heavier textured soils. $\mathrm{N}_{-} \mathrm{NO}_{3}{ }^{-}$determined in the field-moist samples was also higher compared to the dried samples; however, the differences achieved between the samples were not significant. These tendencies were observed in all soil layers.

The data presented in Table 3 indicate that the correlation-regression data analysis showed that the dependence of $\mathrm{N}_{-} \mathrm{NH}_{4}^{+}$concentrations in the field-moist samples $\left(y_{2}\right)$ on the concentrations of this element in the oven-dried samples $\left(x_{2}\right)$ taken from the $0-30$ and 30$60 \mathrm{~cm}$ soil layers was weak $(r=0.300$ and 0.417$)$, and that from the $60-90 \mathrm{~cm}$ was moderately strong $(r=0.564)$. However, in all cases the correlations were statistically significant at a $99 \%$ probability $(p \leq 0.01)$.

Table 3. Relationship between ammonium nitrogen $\left(\mathrm{N}-\mathrm{NH}_{4}^{+}\right)$concentrations in field-moist samples $(y)$ and their concentrations in oven-dried samples $(x)$ in different soil layers

\begin{tabular}{cccc}
\hline \multirow{2}{*}{$\begin{array}{c}\text { Soil layer cm } \\
\text { (cases 519) }\end{array}$} & \multicolumn{2}{c}{$\begin{array}{c}\text { Parameters of equation } \\
y=\mathrm{a}+\mathrm{b} x\end{array}$} & $\begin{array}{c}\text { Correlation } \\
\text { coefficient }\end{array}$ \\
\cline { 2 - 3 } & $\mathrm{a}$ & $\mathrm{b}$ & $r$ \\
\hline $0-30$ & 0.359 & 0.250 & $0.300^{* *}$ \\
$30-60$ & 0.223 & 0.385 & $0.417^{* *}$ \\
$60-90$ & 0.084 & 0.519 & $0.564^{* *}$ \\
\hline
\end{tabular}

** - statistically significant at a $99 \%$ probability $(p \leq 0.01)$

As note Wiltshire and du Preez (1994), $\mathrm{N}_{-} \mathrm{NH}_{4}^{+}$ concentration in soil increased depending on sample drying temperature, and it had almost no effect on nitrate levels. An increase in $\mathrm{N}_{-} \mathrm{NH}_{4}^{+}$release from soil resulting from soil sample drying was also found by the USA researchers. In addition, on the basis of their findings it can be observed, that soil sample drying resulted in higher release of N-NH${ }_{4}^{+}$from the soil plough layer compared to deeper layers (Frye, Hutcheson, 1981).

The highest organic $\mathrm{C}$ and microorganism biomass is accumulated in the arable soil layer (Badalucco, Kuikman, 2001). The intensity of mineralization and nitrification of the organic matter depends not only on moisture and temperature, but also on soil pH (Campbel et al., 1994; Kemmitt et al., 2006). However, the effect of $\mathrm{pH}$ on the activity of microorganisms is greatly reduced, when soil contains low amount of mobile Al and Mn (Curtin et al., 1998; Xiao et al., 2014). For the reasons mentioned above, it is difficult to evaluate the influence of $\mathrm{pH}$ on ammonification and nitrification processes in the soil from the agronomic point of view (Rousk et al., 2009). In addition, ammonia nitrogen in the soil is very mobile (Galloway et al., 2004).

Nevertheless, using the correlation equations presented in Table 3, it is possible to calculate $\mathrm{N}-\mathrm{NH}_{4}^{+}$ concentrations in the field-moist samples theoretically according to the levels of these elements in the oven dried samples taken from the $0-30,30-60$ and $60-90 \mathrm{~cm}$ soil layers. Whereas the dependence is described by linear equations, the relationship derived between the levels of nitrogen in the field-moist and oven-dried soil samples can be used for conversion.

Soil nitrogen content $\left(\mathrm{N}_{\min }=\mathrm{N}-\mathrm{NH}_{4}^{+}+\mathrm{N}-\mathrm{NO}_{3}^{-}\right)$ established in the oven dried soil samples taken from the $0-60 \mathrm{~cm}$ layer is evaluated according to the conditional groups of nitrogen (Staugaitis et al., 2007). It was therefore important to assess the dependence of $\mathrm{N}_{-} \mathrm{NH}_{4}^{+}$ and $\mathrm{N}_{-} \mathrm{NO}_{3}{ }^{-}$concentrations determined in the fieldmoist samples on the concentrations of these elements in the oven-dried samples of soils with different nitrogen content. The studies showed that with an increase of soil mineral nitrogen $\left(\mathrm{N}_{\min }\right)$ content at the 0-60 cm layer, the ratio between $\mathrm{N}^{\min } \mathrm{NO}_{3}^{-}$concentrations in the fieldmoist samples and the concentrations of this element in the oven-dried samples decreased (Table 4). At nitrogen content being $<5.0,5.1-10.0$ and $>10.0 \mathrm{mg} \mathrm{kg}^{-1}$, the ratio

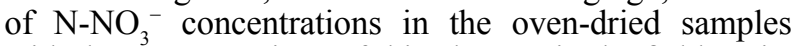
with the concentrations of this element in the field-moist samples was $1: 1.33,1: 1.17$ and $1: 1.11$, respectively.

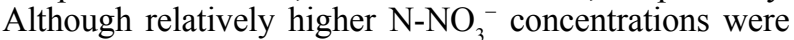
determined in the soils of lower $(<5.0$ and $5.1-10.0 \mathrm{mg}$ $\mathrm{kg}^{-1}$ ) nitrogen content, in actual figures; however, more of those compounds were released from the samples of larger $\left(>10.0 \mathrm{mg} \mathrm{kg}^{-1}\right)$ nitrogen content soils during storage. At nitrogen content (in $0-60 \mathrm{~cm}$ layer) of $<5.0,5.1-10.0$ and $>10.0 \mathrm{mg} \mathrm{kg}{ }^{-1} \mathrm{~N}^{-\mathrm{NO}_{3}}{ }^{-}$levels in the field-moist samples found were $0.68,0.81$ and $1.20 \mathrm{mg} \mathrm{kg}^{-1}$ higher, respectively, compared to the content of this element in the oven-dried samples. The increase of $\mathrm{N}_{-} \mathrm{NO}_{3}^{-}$levels in the field-moist samples was statistically significant compared to the oven-dried ones, except in the case of higher nitrogen content soils with $\mathrm{N}_{\min }>10.0 \mathrm{mg} \mathrm{kg}^{-1}$.

With an increase of soil nitrogen contentN-NH${ }_{4}^{+}$ concentration in soil increased relatively less significantly, when compared to the variations in the levels of $\mathrm{N}_{-} \mathrm{NO}_{3}$ (Table 4). However, having dried the soil samples prior to carrying out chemical analyses, $\mathrm{N}-\mathrm{NH}_{4}{ }^{+}$concentrations found in soil were statistically significantly higher, when compared to the levels of this element in the field-moist samples. At soil nitrogen content of $<5.0,5.1-10.0$ and $>10.0 \mathrm{mg} \mathrm{kg}^{-1} \mathrm{~N}_{-} \mathrm{NH}_{4}^{+}$concentrations in the fieldmoist samples were $1.08,1.21$ and $1.11 \mathrm{mg} \mathrm{kg}^{-1}$ higher, respectively, than those in the oven dried samples. Meanwhile, the ratio between $\mathrm{N}_{-} \mathrm{NH}_{4}^{+}$concentrations in the field-moist samples and the concentrations of this element in the oven-dried samples of the soils with lower nitrogen content was found lower and that of the samples of higher nitrogen content soils - higher.

After the correlation-regression analysis of data, significant correlations between $\mathrm{N}^{-N_{H}}{ }_{4}^{+}$concentrations in the field-moist $\left(y_{1}, y_{2}\right)$ and oven-dried $\left(x_{1}, x_{2}\right)$ soil samples were determined (Table 5). 
Table 4. Ammonium $\left({\mathrm{N}-\mathrm{NH}_{4}+}^{+}\right)$and nitrate $\left(\mathrm{N}-N O_{3}^{-}\right)$nitrogen concentrations in oven-dried and field-moist samples of soils with different mineral nitrogen $\left(\mathrm{N}_{\min }\right)$ contents

\begin{tabular}{|c|c|c|c|c|}
\hline \multirow{4}{*}{$\begin{array}{c}\mathrm{N}_{\min } \text { concentration } \\
\text { in } 0-60 \mathrm{~cm}^{2} \text { soil layer } \\
\mathrm{mg} \mathrm{kg}^{-1}\end{array}$} & \multicolumn{2}{|c|}{$\mathrm{N}-\mathrm{NH}_{4}^{+}$} & \multicolumn{2}{|c|}{$\mathrm{N}-\mathrm{NO}_{3}{ }^{-}$} \\
\hline & \multicolumn{4}{|c|}{ oven-dried samples } \\
\hline & \multicolumn{4}{|c|}{ field-moist samples } \\
\hline & $\mathrm{mg} \mathrm{kg}^{-1}$ & ratio & $\mathrm{mg} \mathrm{kg}^{-1}$ & ratio \\
\hline$<5.0$ & $1.88^{* *}$ & 1 & 2.03 & 1 \\
\hline$(\mathrm{n}=176)$ & 0.80 & 0.42 & $2.71 * *$ & 1.33 \\
\hline $5.1-10.0$ & $2.16^{* *}$ & 1 & 4.63 & 1 \\
\hline$(\mathrm{n}=276)$ & 0.95 & 0.44 & $5.44 * *$ & 1.17 \\
\hline$>10.0$ & $2.24 * *$ & 1 & 10.5 & 1 \\
\hline$(\mathrm{n}=67)$ & 1.13 & 0.50 & 11.7 & 1.11 \\
\hline
\end{tabular}

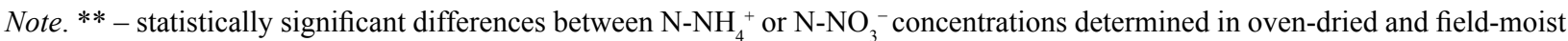
samples at a $99 \%$ probability $(p \leq 0.01)$.

Table 5. Relationship between ammonium nitrogen $\left(\mathrm{N}-\mathrm{NH}_{4}^{+}\right)$concentrations in field-moist samples $(y)$ and its concentration in oven-dried samples $(x)$ of soils with different mineral nitrogen $\left(\mathrm{N}_{\min }\right)$ content

\begin{tabular}{|c|c|c|c|}
\hline \multirow{2}{*}{$\begin{array}{c}\mathrm{N}_{\min } \text { concentration } \\
\text { in } 0-60 \mathrm{~cm} \text { soil layer } \\
\mathrm{mg} \mathrm{kg}^{-1}\end{array}$} & \multicolumn{2}{|c|}{$\begin{array}{l}\text { Parameters of equation } \\
\qquad y=\mathrm{a}+\mathrm{b} x\end{array}$} & \multirow{2}{*}{$\begin{array}{c}\text { Correlation } \\
\text { coefficient } \\
r\end{array}$} \\
\hline & $\mathrm{a}$ & $\mathrm{b}$ & \\
\hline$<5.0(\mathrm{n}=176)$ & 0.036 & 0.404 & $0.392 * *$ \\
\hline $5.1-10.0(n=276)$ & 0.246 & 0.323 & $0.349 * *$ \\
\hline$>10.0(\mathrm{n}=67)$ & 0.514 & 0.274 & $0.358 * *$ \\
\hline
\end{tabular}

** - statistically significant at a $99 \%$ probability $(p \leq 0.01)$

The dependence of $\mathrm{N}-\mathrm{NH}_{4}^{+}$levels in the fieldmoist samples $\left(y_{2}\right)$ on the concentration of this element in the oven-dried samples $\left(x_{2}\right)$ was low $(r=0.349-0.392)$, although statistically significant, at a $99 \%$ probability (Table 4). These trends were observed in all soil nitrogen content groups $\left(<5.0,5.1-10.0\right.$ and $\left.>10.0 \mathrm{mg} \mathrm{kg}^{-1}\right)$.

\section{Conclusions}

1. Drying of soil samples in a thermostatic chamber at a temperature of $35^{\circ} \mathrm{C}$ for 12 hours resulted in significantly higher levels of ammonium nitrogen $\left(\mathrm{N}-\mathrm{NH}_{4}^{+}\right)$compared to those of field-moist samples.

2 . The nitrate nitrogen $\left(\mathrm{N}-\mathrm{NO}_{3}{ }^{-}\right)$concentrations in the field-moist samples, when stored at a $4^{\circ} \mathrm{C}$ temperature for three days, increased marginally compared to the oven-dried soil samples.

3. The $\mathrm{N}_{-} \mathrm{NH}_{4}^{+}$and $\mathrm{N}-\mathrm{NO}_{3}^{-}$concentrations in both oven-dried and field-moist samples depended on the depth of sampling and soil nitrogen content.

4. The concentration ratios of $\mathrm{N}_{-} \mathrm{NH}_{4}^{+}$found between the oven-dried and field-moist samples at different $(0-30,30-60$ and $60-90 \mathrm{~cm})$ soil depths were $1: 0.39,1: 0.52$ and 1:0.58, respectively, and those of $\mathrm{N}-\mathrm{NO}_{3}{ }^{-}-1: 1.20,1: 1.15$ and $1: 1.13$.

5. At nitrogen content being $<5.0,5.1-10.0$ and $>10.0 \mathrm{mg} \mathrm{kg}^{-1}$ in the $0-60 \mathrm{~cm}$ soil depth, the ratio of $\mathrm{N}-\mathrm{NH}_{4}^{+}$concentrations in the oven-dried samples with the concentrations of this element in the field-moist samples was 1:0.42, 1:0.44 and 1:0.50, and that of $\mathrm{N}_{-} \mathrm{NO}_{3}{ }^{-}$was $1: 1.33,1: 1.17$ and $1: 1.11$, respectively.

6. Weak or moderate, however, statistically significant correlations were observed between $\mathrm{N}-\mathrm{NH}_{+}^{+}$ concentrations in the field-moist and oven-dried soil samples.

7. In order to perform faster chemical analyses of soil mineral nitrogen $\left(\mathrm{N}_{\min }\right)$ for making agricultural plant fertilisation plans, it is necessary to carry out analyses on oven-dried soil samples, and using the linear correlation equations, to convert the results ofN-NH${ }^{4+}$ analyses into field-moisture data.

Received 13092017

Accepted 15032018

\section{References}

1. Adomaitis T., Vaisvila Z., Mazvila J., Staugaitis G., Fullen M. A. 2008. Influence of mineral fertilizer on nitrogen leaching. Acta Agriculturae Scandinavica, Section B: Soil and Plant Science, 58 (3): 199-207. https://doi.org/10.1080/09064710701593012

2. Alvarez R., Steinbach H. S. 2009. A review of the effects of tillage systems on some soil physical properties, water content, nitrate availability and crop yields in the Argentine Pamnas. Soil and Tillage Research, 104 (1): 1-15. https://doi.org/10.1016/j.still.2009.02.005

3. Anderson J. M., Ingram J. S. I. 1993. Sampling for laboratory analysis and sample preparation. Anderson J. M., Ingram J. S. I. (eds). Tropical soil biology and fertility ( ${ }^{\text {th }}$ ed.), p. 47-49.

4. Arbačiauskas J., Staugaitis G., Vaišvila Z., Mažvila J., Adomaitis T., Šumskis D., Žičkienè L., Lubytė J., Mažeika R. 2014. The interdependence of mineral nitrogen content in different soil layers of Lithuanian agricultural lands. Zemdirbyste-Agriculture, 101 (2): 133-139. https://doi.org/10.13080/z-a.2014.101.0́17

5. Badalucco L., Kuikman P. J. 2001. Mineralization and immobilization in the rhizosphere. Pinton A. et al. (eds). The rhizosphere: biochemistry and organic substances at the soil-plant interface. New York, USA, p. 159-196.

6. Bogaert N., Salomez J., Vermoesen A., Hofman G., Van Cleemput O., Van Meirvenne M. 2000. Within-field variability of mineral nitrogen in grassland. Biology and Fertility of Soils $30 \cdot 544-549$

https://doi.org/10.1007/s003740000233

7. Bouwman A. F., Van Drecht G., Van der Hoek K. W. 2005. Surface $\mathrm{N}$ balances and reactive $\mathrm{N}$ loss to the environment from global intensive agricultural production systems for the period 1970-2030. Science in China. Series C. Life Sciences, 48: 827-842.

https://doi.org/10.1007/BF03187117

8. Campbell C. A., Jame Y. W., Akinremi O. O., Beckie H. 1994 Evaluating potential nitrogen mineralization for predicting nitrogen requirements of long-term field experiments. Havlin J. L., Jacobson J. S. (eds). Soil testing: prospects for improving nutrient recommendations, p. 81-100.

9. Council Directive 91/676/EEC of 12 December 1991 concerning the protection of waters against pollution caused by nitrates from agricultural sources. Official Journal, L 375: 1-8.

10. Curtin D., Campbell C. A., Jalil A. 1998. Effects of acidity on mineralization: pH-dependence of organic matter mineralization in weakly acidic soils. Soil Biology and Biochemistry, 30 (1): 57-64 https://doi.org/10.1016/S0038-0717(97)00094-1

11. Deressa A. 2014. Effects of soil sample preservation methods on dissolved nitrogen and dissolved organic carbon content in grassland soils fertilized with cattle manure. Journal of Environment and Human, 1 (3): 1-7 https://doi.org/10.15764/EH.2014.03001 
12. Eriksen J., Askergaard M., Søegaard K. 2008. Residual effect and nitrate leaching in grass-arable rotations: effect of grassland proportion, sward type and fertilization. Soil Use and Management. 24: 373-382. https://doi.org/10.1111/j.1475-2743.2008.00178.x

13. Frye W. W., Hutcheson T. B. 1981. Release of $\mathrm{NH}_{4}^{+}$ in soils by oven drying. Soil Science Society of America Journal, 45: 889-892. https://doi.org/10.2̇136/ sssaj1981.03615995004500050014x

14. Füleky G. 2009. Downward movement of fertilizer nitrogen in Hungarian soils. Nawozy i Nawożenie / Fertilizers and Fertilization, 37: 73-89.

15. Galloway J. N., Dentener F. J., Capone D. G., Boyer E. W., Howart R. W., Seitzinger S. P., Asner G. P., Cleveland C. C., Green P. A., Holland E. A., Karl D. M., Michaels A. F., Porter J. H., Townsend A. R., Vöosmarty C. J. 2004. Nitrogen cycles: past, present and future generations. Biogeochemistry. 70: 153-226. https://doi.org/10.1007/s10533-004-0370-0

16. Gray C. J., McLaren R. G. 2003. Effects of air drying or sample storage on soil-solution properties of biosolidsamended soils. Communications in Soil Science and Plant Analysis, 34 (15-16): 2327-2338 https://doi.org/10.1081/CSS-120024067

17. Hill 'I., Levick1 P. 2005. Statistics methods and applications. USA, $800 \mathrm{p}$.

18. Kemmitt S. J., Wright D., Goulding K. W. T., Jones D. L. 2006. $\mathrm{pH}$ regulation of carbon and nitrogen dynamics in two agricultural soils. Soil Biology and Biochemistry, 38: 898-911. https://doi.org/10.1016/j.soilbio.2005.08.006

19. Magesan G. W., White R. E., Scotter D. R., Bolan N. S. 2002. Effect of prolonged storage of soil lysimeters on nitrate leaching. Agriculture, Ecosvstems and Environment, 88 (1): 73-77. https://doi.org/10.1016/S0167-8809(01)00149-9

20. Mengel K., Kirkby E. A. 2001. Nitrogen. Mengel K., Kirkby E. A. (eds). Principles of plant nutrition ( $5^{\text {th }}$ ed.). Kluver Academic Publishers, p. 397-434.

21. Nina D. O., Sigunga D. O. 2012. Effect of drying method, storage period and carbon: nitrogen ratio on inorganic nitrogen contents of Vertisols. African Journal of Environment Science and Technology, 6 (12): 476-482. https://doi.org/10.5897/AJEST12.151
22. Prud'homme M. 2005. Global nitrogen fertilizer supply and demand outlook. Science in China. Series C: Life Sciences, 48 (2): 818-826.

23. Rousk J., Brooks P. C., Bååth E. 2009. Contrasting soil pH effects on fungal and bacterial growth suggest functional redundancy in carbon mineralization. Applied and Fnvironmental Microhiologv. 75: 1589-1596. https://doi.org/10.1128/AEM.02775-08

24. Rutkowska A., Fotyma M. 2009. Calibration of soil test for mineral nitrogen in Poland. Communications in Soil Science and Plant Analysis, 40 (1-6): 987-998. https://doi.org/10.1080/00103620802695115

25. Sparling G. P., Ross D. J. 1988. Microbial contributions to the increased nitrogen mineralization after air-drying of soils. Plant and Soil. 105 (2): 163-167. https://doi.org/10.1007/BF́n'2376779

26. Staugaitis G., Vaisvila L., Mazvila J., Arbaciauskas J., Adomaitis T., Fullen M. A. 2007. Role of soil mineral nitrogen for agricultural crops: nitrogen nutrition diagnostics in Lithuania. Archives of Agronomy and Soil Science, 53 (3): 263-271. https://doi.org/10.1080/03650340701223338

27. Vandendriessche H., Van Neck I., Bijnens U., Elsen A. 2011. Residual soil nitrate: a comparison between airdried and field-moist soil samples. Communications in Soil Science and Plant Analysis, 42 (15): 1847-1854. https://doi.org/10.1080/00103624.2011.587575

28. WHO. 1985. Health hazards from nitrates in drinking water: report on WHO meeting. World Health Organization, Regional Office for Europe, Copenhagen, $102 \mathrm{p}$.

29. Wiesler F., Armbruster M. 2009. The application of the $\mathrm{N}_{\min }$ soil test as an element of integrated nitrogen management strategies in agriculture. Fertilizers and Fertilization, 37: 50-58.

30. Wiltshire G. H., du Preez C. C. 1994. The effect of ovendrying on residual inorganic nitrogen in soils. South African Iournal of Plant and Soil, 11 (2): 107-110 https://doi.org/10.1080/025718́62.1994.10634304

31. Wong M. I. F., Nortclitt S. 1995. Seasonal fluctuations of native available $\mathrm{N}$ and soil management imnlications. Fertilizers Research, 42: 13-26. https://doi.org/10.1007/BF00750496

32. Xiao K., Yu L., Xu J. 2014. pH nitrogen mineralization, and $\mathrm{KCl}$-extractable aluminum as affected by initial soils $\mathrm{pH}$ and rate of vetch residue application: results from laboratory study. Iournal of Soils and Sediments, 14: 1513-1525. https://doi.org/10.1007/s11368-014-0909-1

ISSN 1392-3196 / e-ISSN 2335-8947

Zemdirbyste-Agriculture, vol. 105, No. 2 (2018), p. 99-104

DOI $10.13080 / \mathrm{z}-\mathrm{a} .2018 .105 .013$

\title{
Mineralinis azotas Lietuvos žemės ūkio naudmenų dirvožemiuose: orasausių ir lauko drègnio ėminių palyginimas
}

\author{
J. Arbačauskas, A. Masevičienė, L. Žičkienė, G. Staugaitis \\ Lietuvos agrarinių ir miškų mokslų centro Agrocheminių tyrimų laboratorija
}

\section{Santrauka}

Mineralinis azotas $\left(\mathrm{N}_{\text {min }}=\mathrm{N}-\mathrm{NH}_{4}^{+}+\mathrm{N}_{-\mathrm{NO}_{3}}^{-}\right)$tirtas 2011-2014 m. penkiose Lietuvos vietovėse, orasausius ir lauko drègnio dirvožemio ėminius paẻmus iš skirtingos granuliometrinès sudèties (smèlio, smèlingo priemolio, priemolio ir molio) ir skirtingo azotingumo dirvožemių. Ėminiai buvo imti pavasarị (kovo pabaigoje - balandžio pradžioje) ir rudenị (spalio pabaigoje - lapkričio pradžioje), iš dirvožemio 0-30, 30-60 bei 60-90 cm ir 0-60 cm sluoksnių. Tyrimo tikslas - nustatyti dirvožemio ėminių paruošimo skirtingų metodų įtaką amoniakinio $\left(\mathrm{N}^{-} \mathrm{NH}_{4}^{+}\right)$ir nitratinio $\left(\mathrm{N}_{-} \mathrm{NO}_{3}^{-}\right)$azoto koncentracijoms orasausiuose bei lauko drègnio ėminiuose ir ịvertinti gautų rezultatų tinkamumą sudarant žemès ūkio augalų tręšimo planus.

Tyrimo duomenimis, dirvožemio mėginius termostate džiovinant 12 valandų $35^{\circ} \mathrm{C}$ temperatūroje, amoniakinio azoto nustatoma reikšmingai daugiau, palyginus su lauko drėgnio mėginiais. Nitratinio azoto koncentracija lauko drègnio mėginiuose, juos sandèliuojant 3 paras $4{ }^{\circ} \mathrm{C}$ temperatūroje, padidèjo nežymiai, palyginus su orasausiais. Lauko drègnio ir orasausiuose dirvožemio mėginiuose tarp amoniakinio azoto koncentracijų nustatyti silpni arba vidutinio stiprumo, tačiau esminiai koreliaciniai ryšiai. Sudarant žemės ūkio augalų tręšimo planus ir siekiant greičiau atlikti dirvožemyje esančio mineralinio azoto chemines analizes, reikia analizuoti orasausius dirvožemio méginius, o amoniakinio azoto analizių rezultatus pagal linijinès koreliacijos lygtis perskaičiuoti ị lauko drègnị.

Reikšminiai žodžiai: amoniakinis ir nitratinis azotas, ėminių paruošimas analizèms. 